\title{
PENGARUH PENAMBAHAN BIOAKTIVATOR EM-4 (Effective microorganism) DAN MOL (MIKROORGANISME LOKAL) NASI BASI TERHADAP WAKTU TERJADINYA KOMPOS
}

\author{
Ilham Ramaditya, Hardiono, Zulfikar Ali As \\ Poltekkes Kemenkes Banjarmasin Jurusan Kesehatan Lingkungan \\ Jl. H. Mistar Cokrokusumo No.1A Banjarbaru Kalimantan Selatan 70714 \\ E-mail: ilham11ramaditya@gmail.com
}

\begin{abstract}
Effect Of Addition Bio-Activator EM-4 (Effective microorganism) And Mol (Microorganism Local) Casserole Rice On Timing Of Compost. Composting is the decomposition of organic matter into simple materials is done naturally with the help of microorganisms, but the composting process that occurs naturally long and slow so indispensable ingredient bioactive able to accelerate the composting process. The help of a solution of EM - 4 (Effective microorganism) and MOL (Local Microorganisms) rice casserole that can be accelerated $<2$ months. This study aims to determine differences in the addition of EM - 4 bio-activator (Effective Microrganism) with MOL (Micro Organism Local) Rice Casserole to the time of the compost. The method used in this study is experimental which has been experimenting with the observed variables such as time of compost from each - each treatment well control , EM - 4 as well as the addition of a solution MOL stale rice. Then after the data collected will be followed by a test using a One Way Analisys of Variance, the provisions of $\mathrm{P}$ value $<$ alpha (0.05). The results showed that the value of $p<$ alpha $(0.05)$. So there is the effect of the time difference with the help of compost activator EM-4/MOL rice. Then the three treatments of the fastest time of the end of the composting process is treatment with the addition of a solution of the stale rice MOL (15 days). Based on the results of the study can be recommended to accelerate the composting time can be used activator in the form of EM - 4 or with the help of a solutionbased MOL stale rice.
\end{abstract}

Keywords: Compost; EM - 4; MOL Rice Basi; Time Occurrence Compost.

\begin{abstract}
Abstrak: Pengaruh Penambahan Bioaktivator Em-4 (Effective microorganism) dan Mol (Mikroorganisme Lokal) Nasi Basi Terhadap Waktu Terjadinya Kompos. Pengomposan merupakan penguraian materi organik menjadi bahan sederhana yang dilakukan secara alami dengan bantuan mikroorganisme, namun proses pengomposan yang terjadi secara alami berlangsung lama dan lambat sehingga sangat diperlukan bahan bioaktif yang mampu mempercepat proses pengomposan. Bantuan larutan EM-4 (Effective microorganism) dan MOL (Mikroorganisme Lokal) Nasi Basi sehingga dapat dipercepat $<2$ bulan. Penelitian ini bertujuan untuk mengetahui perbedaan penambahan bioaktivator EM4 (Effective Microrganism) dengan MOL (Mikro Organisme Lokal) Nasi Basi terhadap waktu terjadinya kompos. Metode yang digunakan dalam penelitian ini adalah eksperimental yakni melakukan percobaan dengan variabel yang diamati berupa waktu terjadinya kompos dari masing - masing perlakuan baik kontrol, EM-4 maupun dengan penambahan larutan MOL nasi basi. Kemudian setelah data dikumpulkan akan dilanjutkan dengan uji menggunakan One Way Analisys of Variance, pada ketentuan nilai $\mathrm{P}<$ alpha $(0,05)$. Hasil penelitian menunjukkan bahwa nilai $\mathrm{p}$ <alpha sehingga ada pengaruh perbedaan waktu terjadinya kompos dengan bantuan aktivator EM-4 / MOL nasi basi. Dari ketiga perlakuan yang paling cepat proses pengomposan adalah perlakuan dengan penambahan larutan MOL nasi basi yakni (15 hari). Berdasarkan hasil penelitian dapat direkomendasikan untuk mempercepat waktu pengomposan dapat digunakan aktivator berupa EM-4 atau dengan bantuan larutan MOL yang berbahan dasar nasi basi.
\end{abstract}

Kata Kunci: Kompos; EM-4; MOL Nasi Basi; Waktu Terjadinya Kompos. 


\section{PENDAHULUAN}

Aktivitas manusia dalam memanfaatkan alam selalu meninggalkan sisa yang dianggapnya sudah tidak berguna lagi sehingga diperlakukannya sebagai barang buangan, yaitu sampah dan limbah [1]. Diperkirakan setiap orang menghasilkan sampah organik (baik secara langsung atau tidak langsung) sekitar setengah kilogram per orang per hari. Jika jumlah penduduk Indonesia sebanyak 220 juta, produk sampah organik setiap harinya sebanyak 110.000 ton atau 40.150.000 ton pertahun. Bisa dibayangkan jika sampah sebanyak itu tidak diolah, tentu akan menimbulkan banyak masalah, terutama pencemaran lingkungan [2]. Masalah yang paling besar dalam penanganan sampah organik adalah adanya bau busuk sampah yang menyengat serta kemungkinan banyak bibit penyakit didalamnya. Oleh karena itu, diperlukan teknologi yang ramah lingkungan untuk menghilangkan bau busuk sampah dan mempercepat dekomposisi sampah organik tersebut menjadi kompos [3]. Pembuatan kompos merupakan salah satu alternatif yang dapat dilakukan. Selain dapat mengurangi volume sampah juga bermanfaat bagi tanaman. Pembuatan kompos dari sampah rumah tangga memiliki nilai ekonomis yang tinggi sebab tidak membutuhkan biaya yang banyak serta ramah lingkungan [4].

Pengomposan merupakan penguraian materi organik menjadi bentuk yang lebih sederhana yang dilakukan secara biologis dengan bantuan mikroorganisme dalam kondisi aerobik atau memerlukan oksigen yang terkendali wahyono [5] . Pada prinsipnya pengomposan berdasarkan penguraian bahan organik terjadi secaraalami.Namun proses pengomposan yang terjadi secara alami berlangsung lama dan lambat. Pengomposan dapat dipercepat dengan beberapa cara yaitu dengan memanipulasi kondisi / faktor-faktor yang berpengaruh pada proses pengomposan, menambahkan organisme yang dapat mempercepat proses pengomposan yaitu mikro pendegradasi bahan organik dengan menggunakan bioaktivator pengomposan. Bioaktivator secara umum diartikan sebagai bahan bioaktif yang mampu merombak bahan-bahan organik pada umumnya.Penggunaan bioaktivator EM-4 (Effective Microorganism) dan MOL (Mikroorganisme Lokal) Nasi Basi merupakan langkah sederhana untuk memperoleh kualitas kompos yang baik serta waktu komposting yang dinilai lebih cepat pada proses pengomposan [6].

Larutan EM-4 adalah larutan yang dapat mempercepat proses pengomposan, juga terbukti dapat menghilangkan bau yang timbul selama proses pengomposan berlangsung [7]. Larutan EM-4 merupakan starter yang siap pakai karena sudah tersedia dipasaran, untuk menghemat biaya ada bioaktivator yang lebih murah dan dapat dibuat sendiri, disebut dengan MOL. MOL memiliki kelebihan yakni tidak merusak lingkungan dan juga tidak berbahaya bagi makhluk hidup. Pembuatan MOL salah satunya dapat dilakukan dengan bahan bakunasi bekas atau nasi basi. Nasi basi dapat dijadikan MOL karena adanya kandungan dari karbohidrat yang dihasilkan selama proses fermentasi juga dapat menumbuhkan bakteri atau jamur yang dapat membantu proses pengomposan berlangsung [8].

Berdasarkan uraian diatas pada penelitian ini peneliti ingin melakukan penelitian mengenai pengolahan sampah organik secara sederhana untuk menjadi kompos dengan penambahan bioaktivator EM-4 dan MOL (Mikro Organisme Lokal) Nasi Basi sebagai starter proses pengomposan. Oleh karena itu, peneliti tertarik melakukan penelitian ini.

\section{BAHAN DAN CARA PENELITIAN}

Jenis penelitian yang digunakan adalah penelitian yang bersifat eksperimental. Pada penelitian ini variabel diamati adalah waktu terjadinya kompos, waktu ditentukan sampai proses pengomposan selesai, untuk mengetahui perbedaan dari perlakuan penambahan 
bioaktivator EM-4, MOL nasi basi dan tanpa perlakuan yaitu kontrol.

Desain / rancang bangun penelitian ini adalah Rancangan Post-Test Only Control Group Design, Rancangan penelitian ini dengan melakukan perlakuan penambahan bioaktivator dan MOL serta menggunakan kontrol sebagai pengendali perlakuan, sehingga total perlakuan sebanyak 3 perlakuan dengan masingmasing pengulangan sebanyak 9 kali. Jumlah sampel seluruhnya sebanyak 27 sampel. Bahan yang digunakan berupa sampah organik yang sudah dicacah, dengan campuran sampah daun $(10 \mathrm{~kg})$, sisa makanan (35 kg), buah (6 kg), dan kotoran sapi (3 kg). Masing-masing sampel diisi $2 \mathrm{~kg}$ sampah organik, sehingga total keseluruhan sampah organik yang digunakan adalah $54 \mathrm{~kg}$.

Untuk sampel dengan perlakuan berupa penambahan larutan EM-4 dibutuhkan dosis larutan EM-4 sesuai 1. Keadaan $\mathbf{p H}$ dengan berat sampah organik dengan pedoman 1liter untuk 1 ton campuran sampah, kemudian campurkan dengan gula $5 \mathrm{Kg} /$ ton sampah dan air secukupnya. Untuk sampel dengan perlakuan penambahan larutan MOL Nasi Basi pengaplikasian larutan MOL Nasi Basi dengan pedoman 1 liter untuk 1 ton campuran sampah organik.

Penelitian ini dilakukan juga pengukuran untuk data penunjang berupa parameter $\mathrm{pH}$, suhu dan kelembaban yag dilakukan pengukuran setiap hari. Setelah didapatkan data waktu terjadinya kompos kemudian dilakukan analisis data untuk mengetahui perbedaan waktu yang diperlukan proses komposting, uji statistik yang dipakai menggunakan metode (One Way Analisys of Variance), dengan bantuan program komputer SPSS.

HASIL PENELITIAN DAN PEMBAHASAN Hasil Penelitian

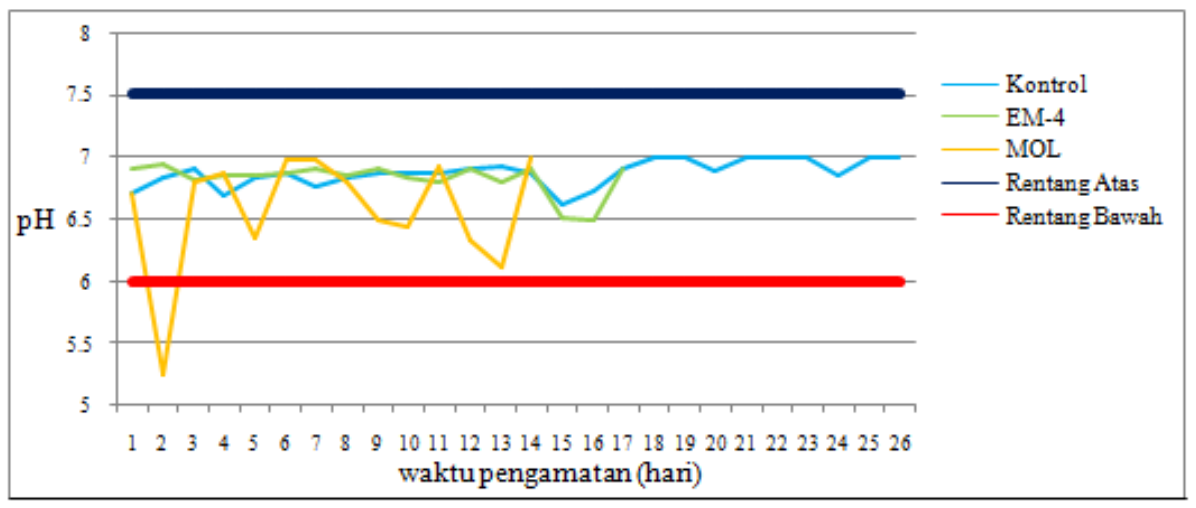

Gambar 1. Grafik Rata-Rata Keadaan Ph Masing-Masing Perlakuan Selama Proses Pengomposan

Dari ketiga perlakuan tersebut keadaan $\mathrm{pH}$ mengalami fluktuasi pada hari pertama sampai berakhirnya proses pengomposan hal ini menunjukan bahwa semua perlakuan mengalami proses pengomposannya sendiri, namun semakin lama sampai berakhirnya pengomposan keadaan $\mathrm{pH}$ akan menunjukan keadaan normal di kisaran 7.

\section{Keadaan Suhu}




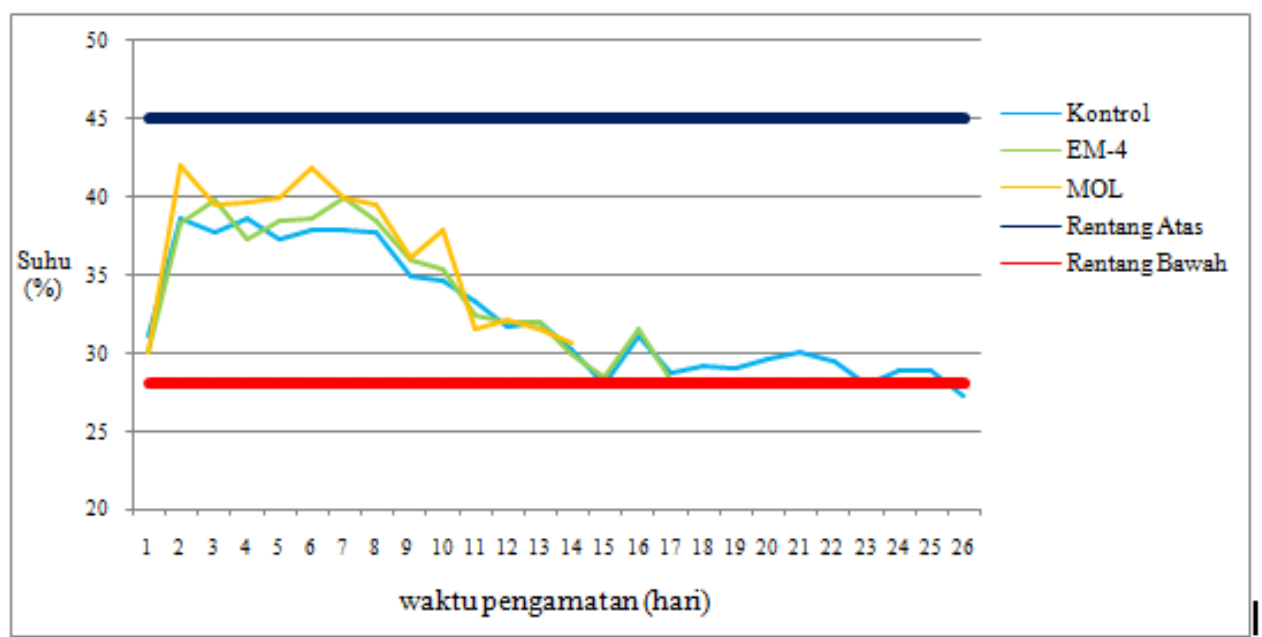

Gambar 2. Grafik Rata-Rata Keadaan Suhu Masing-Masing Perlakuan Selama Proses Pengomposan

Dari grafik terlihat mulai hari kedua terjadi peningkatan untuk semua perlakuan, lalu terjadi penurunan pada hari ke delapan yang secara umum menunjukan suhu $30{ }^{\circ} \mathrm{C}$ sampai kompos menandakan kematangan yakni menunjukan bahwa suhu mendekati suhu lingkungan / suhu tanah yang berkisar 25
- $28^{\circ} \mathrm{C}$ untuk masing - masing perlakuan. Sehingga dari masing - masing perlakuan menunjukan bahwa berakhirnya proses pengomposan yakni pada kontrol (hari 26), EM-4 (hari 17) dan MOL nasi basi (hari 14).

\section{Keadaan Kelembaban}

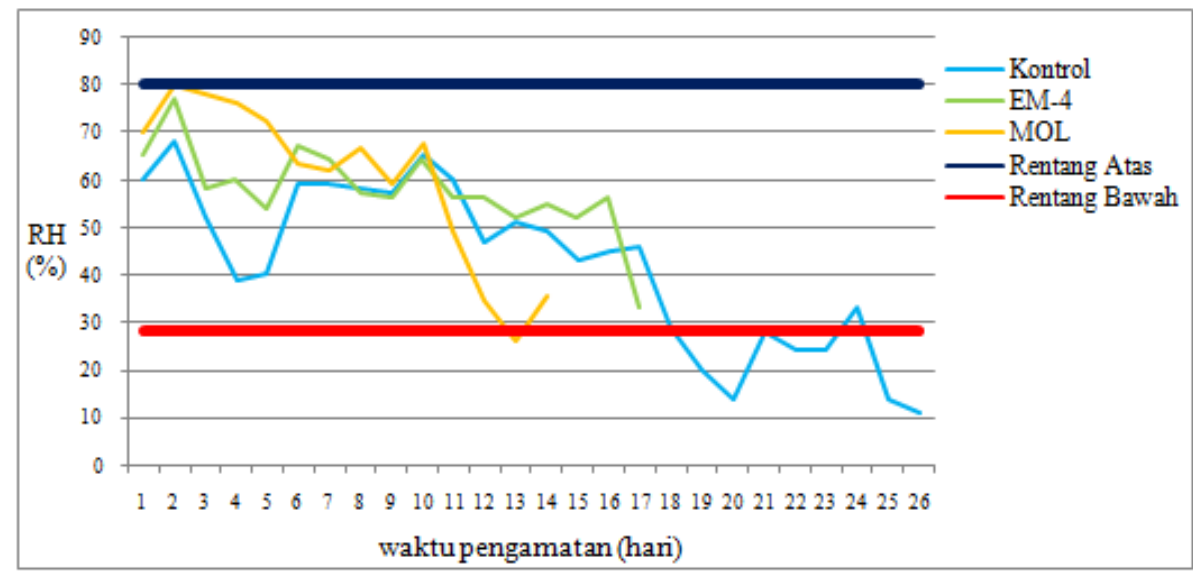

Gambar 3. Grafik Rata-Rata Keadaan Kelembaban Masing-Masing Perlakuan Selama Proses Pengomposan

Berdasarkan grafik diatas dapat dilihat bahwa kelembaban untuk semua perlakuan tersebut, masih berada dalam batas rentang yang dianjurkan yakni 60 80 \%untuk proses pengomposan. Namun pada hari terakhirkelembaban pada kelompok control yang $<30 \%$.

\section{Waktu Terjadinya Kompos}


Ilham Ramaditya, Hardiono, Zulfikar Ali As. Pengaruh Penambahan

Tabel 1. Waktu Terjadinya Kompos Tiap Perlakuan

\begin{tabular}{cccc}
\hline Ulangan & Kontrol & $\begin{array}{c}\text { Perlakuan } \\
\text { EM-4 }\end{array}$ & MOL Nasi Basi \\
\hline 1 & 28 & 20 & 14 \\
2 & 29 & 17 & 15 \\
3 & 30 & 20 & 14 \\
4 & 29 & 17 & 16 \\
5 & 26 & 18 & 14 \\
6 & 28 & 19 & 17 \\
7 & 30 & 20 & 16 \\
8 & 29 & 21 & 15 \\
9 & 27 & 20 & 18 \\
Total & 256 & 172 & 139 \\
Rata-rata & 28 & 19 & 15 \\
\hline
\end{tabular}

Berdasarkan tabel diatas menunjukan rata - rata waktu terjadinya kompos yang paling lama terdapat pada kelompok kontrol, sedangkan yang paling singkat pada kelompok dengan perlakuan penambahan MOL nasi basi.

\section{Uji Statistik}

Untuk membuktikan apakah ada perbedaan waktu terjadinya kompos secara statistik bermakna maka akandigunakan uji ANOVA (Analysis of Variance),

UjiANOVA digunakan mengingat berdasarkan uji homogenitas dan uji normalitas didapatkan bahwa data homogen dan berdistribusi normal.Hasil uji ANOVA didapatkanhasil nilai $\mathrm{p}=$ $0,000<$ alpha $(0,05)$ maka Ho ditolak, dapat disimpulkan minimal 2 pasang perlakuan yang berbeda rata - rata waktu terjadinya kompos. Hasil pengujian dapat dilihat pada tabel 2 berikut:

Tabel 2. Analisys Of Variance (ANOVA) Waktu Terjadinya Kompos

\begin{tabular}{lrrrcc}
\hline & Sum of squares & \multicolumn{1}{c}{ Df } & Mean Square & $F$ & Sig. \\
\hline Between Groups & 808.667 & 2 & 404.333 & 205.014 & .000 \\
Within Groups & 47.333 & 24 & 1.972 & & \\
Total & 856.000 & 26 & & & \\
\hline
\end{tabular}

Untuk mengetahui perlakuan mana yang berbeda dilakukan uji LSD (Least Significance Different), hasil pengujian dapat dilihat pada Tabel 3 berikut:

Tabel 3. Uji Post Hoc Test (One Way ANOVA)

\begin{tabular}{lll}
\hline Perlakuan Kompos & \multicolumn{1}{c}{ Perlakuan Kompos } & $\begin{array}{c}\text { Rata-rata Waktu } \\
\text { Terjadinya Kompos }\end{array}$ \\
\hline Kontrol (a) & EM-4(b) & $9,333^{*}$ \\
& Mol Nasi Basi (c) & $13,000^{*}$ \\
EM-4 (b) & Kontrol (a) & $-9,333^{*}$ \\
& Mol Nasi Basi (c) & $3,667^{*}$ \\
Mol Nasi Basi (c) & Kontrol (a) & $-13,000^{*}$ \\
& EM-4(b) & $-3,667^{*}$ \\
\hline Keterangan: & &
\end{tabular}


Berdasarkan tabel 3 tersebut dapat disimpulkan sebagai berikut: 1). Kontrol berbeda dengan EM-4, 2). Kontrol berbeda dengan MOL nasi basi dan 3). EM-4 berbeda dengan MOL nasi basi.

\section{Pembahasan}

\section{Pengaruh \\ Penambahan \\ Biokativator EM-4 terhadap Waktu Terjadinya Kompos}

Berdasarkan hasil uji statistik menunjukan bahwa terdapat perbedaan yang bermakna dari waktu terjadinya kompos antara penambahan larutan EM-4 dengan kontrol, dimana untuk EM-4 membutuhkan waktu pengomposan 19 hari sedangkan untuk kontrol yakni 28 hari. Dapat disimpulkan jika dibandingkan dengan kontrol bahwa dengan penambahan larutan EM-4 dapat mempercepat proses pengomposan dari selisih 9 hari.

Hal tersebut dibuktikan bahwa larutan EM-4 mengandung bakteri yang dapat membantu penguraian bahan organik, sehingga dapat mempercepat proses pengomposan. Hal ini juga dijelaskan bahwa menurut Indriani (2011), mikroorganisme tersebut dipilih yang dapat bekerja secara efektif dalam memfermentasikan bahan organik. Dari sekian banyak mikroorganisme, ada lima golongan utama yang terkandung di dalam EM4, yaitu Bakteri fotosintetik, Lactobacillus sp. (bakteri asam laktat), Streptomyces sp., Ragi/yeast, dan actinomycete [9].

Kemudian didalam EM-4 juga dibuktikan bahwa secara ilmiah dapat berperan mempercepat fermentasi limbah dan sampah organik, menekan pertumbuhan patogen tanah. meningkatkan ketersediaan unsur hara dan senyawa organik pada tanaman, meningkatkan aktivitas mikroorganisme indogenus yang menguntungkan seperti Mycorrhiza sp., Rhizobium sp., dan bakteri pelarut fosfat, meningkatkan nitrogen, dan mengurangi kebutuhan pupuk dan pestisida kimia.

EM-4 juga bermanfaat untuk menghilangkan bau pada limbah dan mempercepat pengolahan limbah. EM-4 dapat digunakan untuk memproses bahan limbah menjadi kompos dengan proses yang lebih cepat dibandingkan dengan pengolahan limbah secara tradisional.

\section{Pengaruh Penambahan MOL Nasi Basi Terhadap Waktu Terjadinya Kompos}

Berdasarkan hasil uji statistik menunjukan bahwa terdapat perbedaan yang bermakna dari waktu terjadinya kompos antara penambahan larutan MOL nasi basi dengan kontrol, dimana untuk MOL nasi basi membutuhkan waktu pengomposan 15 hari sedangkan untuk kontrol yakni 28 hari. Dapat disimpulkan jika dibandingkan dengan kontrol bahwa dengan penambahan larutan MOL nasi basi dapat mempercepat proses pengomposan dari selisih 13 hari.

Hal tersebut dikarenakan larutan MOL nasi basi mengandung bakteri yang dapat mempercepat proses pengomposan. Kandungan bakteri yang terdapatdalam MOL berbahan dasar nasi basi adalah Sacharomyces sp. dan lactobaciluus sp., hal ini dijelaskan bahwa dalam bakteri tersebut mengandung mikroorganisme pengurai dan dapat menyuburkan tanaman. Inilah yang membuktikan bahwa kandungan dari MOL dapat mempercepat proses pengomposan [10].

Adapun penelitian yang serupa tentang MOL berbahan baku nasi basi oleh Nurullita dkk, (2012) peneliti membandingkan lama waktu pengomposan dari berbagai macam aktivator dan MOL, berdasarkan penelitian tersebut bahwa penggunaan MOL nasi basi sebagai 
bahan aktivator pembuatan kompos hanya membutuhkan waktu berkisar 8 hari atau hanya kurun waktu $<2$ minggu [11]. Kemudian pendapat lain juga menjelaskan oleh Budiman dkk (2010) bahwa semakin banyak jenis mikroorganisme dalam MOLmaka waktu pengomposan semakin cepat ini membuktikan bahwa penggunaan MOL nasi basi dapat mempercepat proses pengomposan [12].

Hal ini juga menunjukan bahwa kompos dengan bantuan larutan MOL nasi basi.mempunyai keuntungan berupa waktu yang singkat. MOL adalah cairan yang mengandung mikroorganisme hasil produksi sendiri dari bahan-bahan alami, dimana bahan-bahan tersebut berperan sebagai media untuk hidup dan berkembangnya mikoorganisme yang berguna mempercepat penghancuran bahan-bahan organik (dekomposer) atau sebagai tambahan nutrisi bagi tanaman. Larutan MOL mengandung unsur hara mikro dan makro dan juga mengandung bakteri yang berpotensi sebagai perombak bahan organik, perangsang pertumbuhan dan MOL juga dapat digunakan sebagai dekomposer/pupuk hayati. Keunggulan penggunaan MOL yang paling utama adalah berbiaya murah. Bahan-bahan yang digunakan untuk membuat MOL harus mengandung karbohidrat, glukosa, dan bakteri. Ketiga komponen tersebut menjadi sangat penting untuk diperhatikan agar MOL yang dihasilkan berkualitas dan sesuai dengan harapn. MOL bermanfaat sebagai pupuk cair ataupun pestisida nabati sesuai dengan bahan baku yang digunakan [13].

3. Analisis Perbedaan Pengaruh Penambahan Bioaktivator EM-4 dengan MOL Nasi Basi terhadap Waktu Terjadinya Kompos

Berdasarkan hasil uji statistik menunjukan bahwa terdapat perbedaan yang bermakna dari waktu terjadinya kompos antara penambahan larutan EM-4 dengan penambahan larutan MOL nasi basi, dimana untuk EM-4 membutuhkan waktu pengomposan selama 19 hari sedangkan untuk MOL nasi basi yakni 15 hari. Dapat disimpulkan bahwa jika dibandingkan dengan EM-4 dengan penambahan larutan MOL nasi basi dapat mempercepat proses pengomposan dari selisih 4 hari.

Hal tersebut dikarenakan larutan MOL nasi basi mengandung bakteri yang dapat mempercepat proses pengomposan. Kandungan bakteri tersebut berupa Sacharomyces sp. dan lactobaciluus sp., hal ini juga dikuatkan bahwa dalam bakteri tersebut mengandung mikroorganisme pengurai dan dapat menyuburkan tanaman. Inilah yang membuktikan bahwa kandungan dari MOL dapat mempercepat proses pengomposan [10].

Dalam penelitian Nurullita dkk (2012) juga menguatkan bahwa dengan bantuan MOL berbahan dasar nasi basi pembuatan kompos hanya membutuhkan waktu berkisar 8 hari atau hanya kurun waktu $<2$ minggu [11]. Menurut Lamapaha dkk (2013) ada beberapa keuntungan penggunaan MOL berbahan dasar nasi basi yakni mendukung pertanian yakni ramah lingkungan, dapat mengatasi permasalahan limbah rumah tangga, serta pembuatan aplikasinya mudah dilakukan, dan mengandung unsur kompleks mikroba yang bermanfaat dalam produksi pupuk atau dekomposer organik yang dihasilkan [8].

Menurut Lindung (2013)

pada prinsipnya kandungan bakteri yang terdapat dalam larutan MOL ataupun EM-4 hampir sama tergantung dari bahan pembuatannya dan perlu dilakukan penelitian lebih lanjut tentang kandungan sebenarnya [14]. Hasil tersebut menunjukan bahwa dengan penggunaan EM-4 
ataupun MOL berbahan dasar nasi basi dapat diperpendek hanya $<1$ bulan. Pengomposan yang terjadi secara alami memang membutuhkan waktu relatif lama yakni $>2$ bulan [15]. Untuk mengatasi hal tersebut, perlu dilakukan mokulasi mikroba terpilih guna mempercepat proses perombakan bahan organik. Pemberian mikroba aktivator pada proses pengomposan dapat mempercepat proses menjadi 2 - 3 minggu atau 1 - 1,5 bulantergantung dari bahan dasarnya [16]. Maka dari itu perlunya penambahan biokatif yang mampu mempercepat dalam proses pengomposan.

\section{KESIMPULAN DAN SARAN}

$\begin{array}{rrr}\text { Rata-rata } & \text { waktu terjadinya } \\ \text { kompos pada perlakuan dengan }\end{array}$ penggunaan MOL nasi basi membutuhkan waktu yang paling cepat rata - rata 15 hari, penambahan larutan EM-4 rata - rata waktu 19 hari, dan kontrol selama 28 hari.

Berdasarkan hasil uji statistik menunjukan bahwa ada perbedaan yang bermakna dari waktu terjadinya kompos pada masing-masing perlakuan yakni kontrol, penambahan dengan larutan EM4 dan penambahan dengan larutan MOL nasi basi dengan nilai $p=0,000<$ alpha $(0,05)$.

Pengomposan dapat berjalan dengan cepat jika dalam kompos terdapat bakteri yang dapat mempercepat proses pengomposan. Penambahan larutan EM4/MOL berbahan dasar nasi basi adalah upaya yang dapat dilakukan untuk percepatan pembuatan dengan kisaran < 1 bulan. Cara yang dapat dilakukan untuk memvariasikan metode pengomposan selain dengan larutan MOL yang berbahan dasar nasi basi dapat juga digunakan MOL dengan bahan seperti bonggol pisang, buah-buahan busuk, sisa makanan dan bahan lain yang mudah menghasilkan bakteri untuk pembuatan kompos.

\section{KEPUSTAKAAN}

1. Widyatmoko, \& Sintorini. (2006). Menghindari, Mengolah, dan
Menyingkirkan Sampah. Jakarta: PT. Dinastindo Adiperkasa Internasional.

2. Sofian. (2006). Sukses Membuat Kompos dari Sampah. Jakarta Selatan : AgroMedia Pustaka.

3. Kastaman, R., \& Moetangad, A. (2006). Perancangan Reaktor Sampah Terpadu Dan Pengembangan Mikroba Penghilang Bau Sampah Dalam Rangka Mengatasi Masalah Sampah Di Perkotaan . Fakultas Pertanian, Universitas Padjajaran Jatinangor , 3.

4. Wellang, R. M., \& dkk. (2015). Studi Kelayakan Kompos Menggunakan Variasi Bioaktivator. Jurnal acc , 3.

5. Wahyono, S., \& dkk. (2011). Membuat Pupuk Organik Granul dari Aneka Limbah. Jakarta: Agromedia Pustaka.

6. Srihartati, \& dkk. (2008). Pemanfaatan Limbah Sari Buah Jambu Biji (Psidium Guajaya L) untuk Pembuatan Kompos dengan Menggunakan Berbagai Bahan Aktivator. Prosiding Seminar Nasional Teknoin Bidang Teknik Kimia dan Tekstil.

7. Suwahyono, U. (2014). Cara Cepat Buat Kompos Dari Limbah. Jakarta: Penebar Swadaya.

8. Lamapaha, H. E., \& dkk. (2013). Penerapan Mol (Mikroorganisme Lokal) Dari Nasi Bekas. Pkm Pengabdian Kepada Masyarakat .

9. Indriani, Y. H. (2011). Membuat Kompos Secara Kilat. Jakarta: Penebar swadaya.

10. Bahr, F. (2012). Membuat Aneka Bahan Pertanian Organik. Draft Pembuatan Aneka Bahan Organik: Scrib .

11. Nurullita, U., \& dkk. (2012). Lama Waktu Pengomposan Sampah Rumah Tangga Berdasarkan Mikro Organisme Lokal (MOL) dan Teknik Pengomposan . http://jurnal unimus.ac.id .

12. Budiman, \& dkk. (2010). Pengaruh Jenis Starter, Volume Pelarut, dan Aditif terhadap Pengolahan Sampah Organik Rumah Tangga Menjadi Pupuk Kompos Secara Anaerob. Prosiding Seminar Nasional Teknik 
Kimia "Kejuangan" Pengembangan Teknologi Kimia untuk Pengelolaan Sumber Daya Alam Indonesia, UPN Veteran Yogyakarta.

13. kknm.unpad.ac.id. (2015). Program Kerja Penyuluhan Mikroorganisme Lokal (MOL). Cibanten: Cibanten Pangandaran, 2015.

14. Lindung. (2013). Teknologi Mikro Organisme EM-4 dan MOL. Widyaiswara BPP JAMBI.

15. Rohmawati, D. (2016). Pembuatan Kompos Dengan MOL Limbah Organik. Kompos MOL.

16. Surakarta.go.id, T. (2015). Pengolahan Sampah Organik "Pengomposan". Sains dan Edukasi. 
424 Jurnal Kesehatan Lingkungan Vol. 14 No. 1 Januari 2017 